\title{
Making Heads or Tails of It: Cell-Cell Adhesion in Cellular and Supracellular Polarity in Collective Migration
}

\author{
Jan-Hendrik Venhuizen and Mirjam M. Zegers \\ Department of Cell Biology, Radboud Institute for Molecular Life Sciences, 6525 GA Nijmegen, \\ The Netherlands \\ Correspondence: mirjam.zegers@radboudumc.nl
}

Collective cell migration is paramount to morphogenesis and contributes to the pathogenesis of cancer. To migrate directionally and reach their site of destination, migrating cells must distinguish a front and a rear. In addition to polarizing individually, cell-cell interactions in collectively migrating cells give rise to a higher order of polarity, which allows them to move as a supracellular unit. Rather than just conferring adhesion, emerging evidence indicates that cadherin-based adherens junctions intrinsically polarize the cluster and relay mechanical signals to establish both intracellular and supracellular polarity. In this review, we discuss the various functions of adherens junctions in polarity of migrating cohorts.

M any physiological functions, including morphogenesis, immune surveillance, and wound healing, rely on the ability of cells to migrate. In a pathological context, deregulated cell migration is required for cancer cell dissemination from the primary tumor. Cells may either migrate as single cells or through collective migration, and a central aspect for both types of cell migration is how cells control directional movement. This process is best understood for single fibroblast-like cells migrating on flat surfaces, termed mesenchymal cell migration. This type of directional migration involves frontrear polarization, in which a frontal actin-based protrusion, or leading edge, drives forward movement, whereas an actomyosin-dependent translocation of the cell body causes retraction of the cell rear (Ridley et al. 2003). Collective cell migration is defined as migration of multicellular cohorts in which directional cell movements are interdependent and coordinated through stable or transient cell-cell contacts. This type of migration is particularly prevalent during embryonic development and tissue homeostasis, but also drives carcinoma invasion (Friedl and Gilmour 2009). Typical well-studied in vivo model systems for collective migration include the embryonic movements of Drosophila melanogaster border cells and tracheal system, the zebrafish lateral line, mouse retinal angiogenic sprouting, branching morphogenesis of vertebrate mammary gland, lung, and kidney, and cancer invasion models (Friedl and Gilmour 2009; Rorth 2012; Scarpa and Mayor 2016). Cell culture models for collective migration include 3D tumor cell invasion or branching mor-

Editor: Keith E. Mostov

Additional Perspectives on Cell Polarity available at www.cshperspectives.org

Copyright (C) 2017 Cold Spring Harbor Laboratory Press; all rights reserved; doi: 10.1101/cshperspect.a027854 Cite this article as Cold Spring Harb Perspect Biol 2017;9:a027854 
phogenesis from mammary and kidney cell epithelia, and 2D epithelial sheet migration models (Fig. 1) (Reffay et al. 2014; Zegers 2014; Nguyen-Ngoc et al. 2015).

The maintenance of cell-cell contacts is a defining feature of collective migration, and is a central regulator of directional movement. Migrating cell cohorts mainly adhere to each other through cadherin-based adherens junctions. Cadherins are transmembrane cell-cell adhesion receptors that link to the actin cytoskeleton through cytoplasmic binding partners that in- clude $\alpha$ - and $\beta$-catenin. They also bind cytoplasmic p120 catenin (p120), which stabilizes cadherin at the membrane and regulates Rho GTPases (Ratheesh and Yap 2012). Consequently, cadherin expression, dynamics, and downstream signaling control cellular adhesion and coordinate cohesive cell behaviors during collective migration. Here, we discuss supracellular and subcellular directional polarity of migrating cell collectives and the regulatory roles of adherens junctions in these polarities. As many of the concepts have been initially established in mes-
A

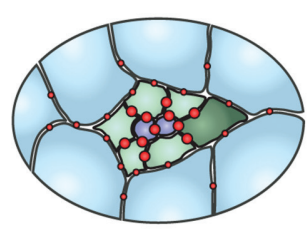

E

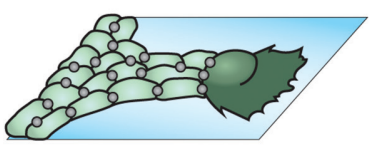

B

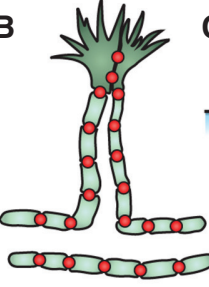

$\mathbf{F}$

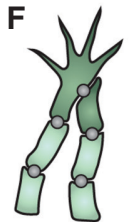

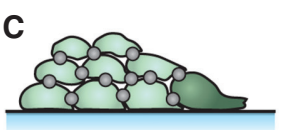

D

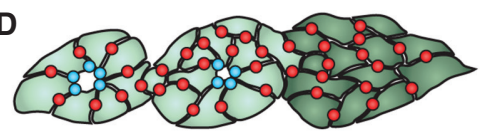

G

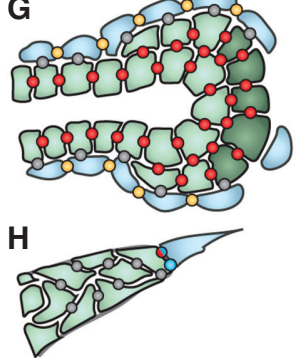

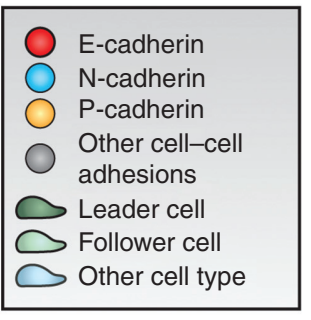

Figure 1. Models of collective migration. (A) Drosophila border cell cluster. Cluster of two polar cells (purple) surrounded by epithelial cells migrating between nurse cells (blue). Main adhesion molecule: Drosophila epithelial (DE)-cadherin (in order of decreasing expression: polar cells, border cells, nurse cells) (Niewiadomska et al. 1999; Cai et al. 2014). (B) Drosophila tracheal branching. Branches sprout from dorsal trunk by active migration of the leader cell and elongation and intercalation of follower cells. Follower cells are also polarized apicobasally toward the lumen (Lebreton and Casanova 2014). Main adhesion molecule: DE-cadherin (Affolter and Caussinaus 2008). (C) Xenopus mesendoderm. Migrates as a multilayered sheet over fibronectin-rich extracellular matrix (ECM). Leader and follower cells in contact with the ECM show front-rear polarization and extend lamellipodia. Main adhesion molecule: C-cadherin (Weber et al. 2012). (D) Zebrafish lateral line. Leading zone is polarized in the direction of migration. Behind the leading zone, there is a transitional zone in which cells acquire apicobasal polarity and are organized into rosette-like sensory organs. Main adhesion molecules: E-cadherin (throughout), N-cadherin (accumulates apically at rosette) (Revenu et al. 2014). (E) Wound healing assay. 2D sheet migration assay, in which a gap is created in a confluent monolayer. Leader cells extend lamellipodia and migrate into the wound area. Main adhesion molecules: cell-type dependent. $(F)$ Vascular sprouting. Migrates as cord with lumen led by two leader cells. The trailing cells elongate parallel but polarize apicobasally perpendicularly to the direction of migration (Lee and Bautch 2011). Main adhesion molecule: vascular endothelial (VE)-cadherin. $(G)$ Mammary branching. Migration of multilayered structure called terminal end bud (TEB) consisting of luminal epithelial cells that lose apicobasal polarity but retain Ecadherin and are partially covered by myoepithelial cells (blue). Leader cell in the TEB lack protrusive structures (Ewald et al. 2012). Main adhesion molecules: myoepithelial cells, P-cadherin; luminal epithelial cells, Ecadherin (Knudsen and Wheelock 2005). (H) Heterotypic cancer cell migration. Cancer cohorts may recruit other cell types (blue), such as fibroblasts or myeloid cells as leader cells (Gaggioli et al. 2007; Kitamura et al. 2007; Li et al. 2016). Main adhesion molecules: Heterotypic E-N-cadherin contacts (Omelchenko et al. 2001) or homotypic N-N and tight junctions (Smalley et al. 2005). 
enchymal cells, we will first discuss general principles of single-cell front-rear polarization. Next, we will focus on leader cells, which comprise the supracellular front of a collective, but also show front-rear polarization at the cellular level. We will end with defining cell polarity in follower cells. We will mostly discuss collective epithelial movements, which maintain relatively stable adhesion. Loosely connected mesenchymal cohorts also engage in collective migration, for instance, in Xenopus leavis neural crest. Mesenchymal collective migration has been extensively reviewed elsewhere (Theveneau and Mayor 2012; Scarpa and Mayor 2016) and will not be discussed in detail.

\section{GENERAL MECHANISMS IN SINGLE-CELL FRONT-REAR POLARIZATION}

Front-rear polarization in single migrating cells can be induced by many external guidance cues, including chemokines, growth factors, and the composition, organization, and physical properties of the extracellular matrix (ECM) (Haeger et al. 2015; Scarpa and Mayor 2016) through activation of ECM adhesion receptors, receptor tyrosine kinases, (RTKs) or G-proteincoupled receptors (Ladoux et al. 2016). Polarity initiated at the nascent front involves activation of phosphoinositide 3-kinase (PI3K) and the Rho family GTPases Rac and cdc42, reinforced by positive feedback loops (Campa et al. 2015). Like all Rho GTPases, Rac and cdc42 cycle between an active, GTP-bound state, induced by guanine exchange factors (GEFs), and an inactive GDP-bound state, induced by GTPase-activating proteins (GAPs). They act as molecular switches that bind and activate many different effector proteins, many of which are involved in regulating the cytoskeleton (Zegers and Friedl 2014). The switch-like behavior of Rho GTPases, coupled with the high turnover rates of the lipid products of PI3K, allows for dynamic spatiotemporal regulation, which is required for effective directional cell migration.

Frontal activation of cdc42 and Rac is a central event in forward protrusion and depends on the recruitment of GEFs by growth factor receptors or cell-ECM adhesions. Integrins, hetero- dimeric $\alpha \beta$ transmembrane ECM receptors, assemble in cell-ECM adhesion complexes (Huttenlocher and Horwitz 2011) and recruit Rac/cdc42 GEFs, including DOCK180 and $\beta$ PIX (Goicoechea et al. 2014). Cdc42 prominently regulates cell polarity by interacting with two conserved polarity complexes at the leading edge, the Scribble complex, consisting of Scribble, Discs large, and Lethal giant larvae, and the Par complex, consisting of Par3, Par6, and atypical PKC (aPKC). Although mostly known for regulating apicobasal epithelial polarity (Nelson 2009), these complexes promote front-rear polarization by mechanisms that include Scribble-mediated recruitment of BPIX (Audebert et al. 2004; Osmani et al. 2010) and assembly of the Par complex (Nelson 2009), which recruits the RacGEF Tiam-1, leading to Rac activation (Nishimura et al. 2005; Pegtel et al. 2007). In parallel, GEFs are locally activated by RTKs (Goicoechea et al. 2014; Campa et al. 2015). Activated Rac and cdc42 promote cell protrusion through lamellipodia and filopodia driven by actin polymerization, most prominently via the Arp $2 / 3$ complex and WAVE-family proteins (Ridley 2015). In addition, cdc42/Rac locally stabilize microtubules (Etienne-Manneville and Hall 2003; Ellenbroek et al. 2012) that further promote polarity of the leading edge by (1) vesicular delivery of signaling molecules, including Rac, cdc42, and BPIX (Palamidessi et al. 2008; Osmani et al. 2010); (2) delivery of migration-associated mRNAs (Mili et al. 2008); (3) orienting the centrosome toward the leading edge, which, together with a rearward orientation of the nucleus (Dupin et al. 2009), aligns the nucleus-microtubule organizing center (MTOC) axis with the direction of migration; and (4) regulation of focal adhesion turnover (Wu et al. 2008). At the cell rear, Rho activity is high, partially owing to negative feedback signaling between Rac/cdc42 and Rho (Goicoechea et al. 2014). Active Rho, through its main effector ROCK, promotes actomyosin activity by ROCK-mediated phosphorylation of myosin light chain, thereby driving retraction of the cell rear (Vicente-Manzanares et al. 2009). The roles of cdc42, Rac, and Rho in single-cell migration as outlined above only highlight conserved 
J.-H. Venhuizen and M.M. Zegers

general mechanisms, and many alternatives exist. Rho GTPase signaling is highly complex and outcomes depend on the involvement of specific family members, downstream effectors, and regulatory factors, including GAPs and GEFs. For example, in addition to their function at the rear, RhoA and RhoC act at the leading edge to contribute to traction forces (Reffay et al. 2014), local Rac inhibition (Machacek et al. 2009), or cofilin-dependent lamellipodia extension (Bravo-Cordero et al. 2013).

\section{SUPRACELLULAR POLARIZATION OF MIGRATING CELL COLLECTIVES: LEADER CELL FUNCTION AND SELECTION}

Collectively moving cohorts polarize at the supracellular level for efficient migration (Fig. 2 ). The front of the cohort is highly specialized, and consists of cells called leader or tip cells, which detect guidance cues, control the direction of migration, and remodel the ECM (Khalil and Friedl 2010; Weavers and Skaer 2014). Leader cells in many systems are morphologically distinguishable from follower stalk cells by their prominent pseudopodia aimed at forward motion (Ochoa-Espinosa and Affolter 2012). In other models lacking protrusive structures, such as branching tubular organs, including the lung, kidney, and mammary gland, leader cells cannot be distinguished by morphological criteria but are functionally defined based on a migratory response to RTK ligands, increased proliferation rates, and distinct gene-expression patterns (Costantini 2006; Gray et al. 2010). The mechanisms driving the forward movement of these leader cells are still poorly defined but may depend on patterned and oriented cell divisions (Weavers and Skaer 2014).

Cells compete with their neighbors for leader cell fate and position, which occurs through a combination of extrinsic and intrinsic factors. As a general concept, extrinsic factors include the relative proximity and level of exposure to chemical or mechanical guidance cues, whereas intrinsic factors include the intracellular responsiveness to these cues. For instance, the ability of cells to activate a RTK-Ras-PI3KRac signaling module in response to ligands directly relates to its chance to move to the front and assume leader cell fate in many different systems (Vitorino and Meyer 2008; Chi et al.
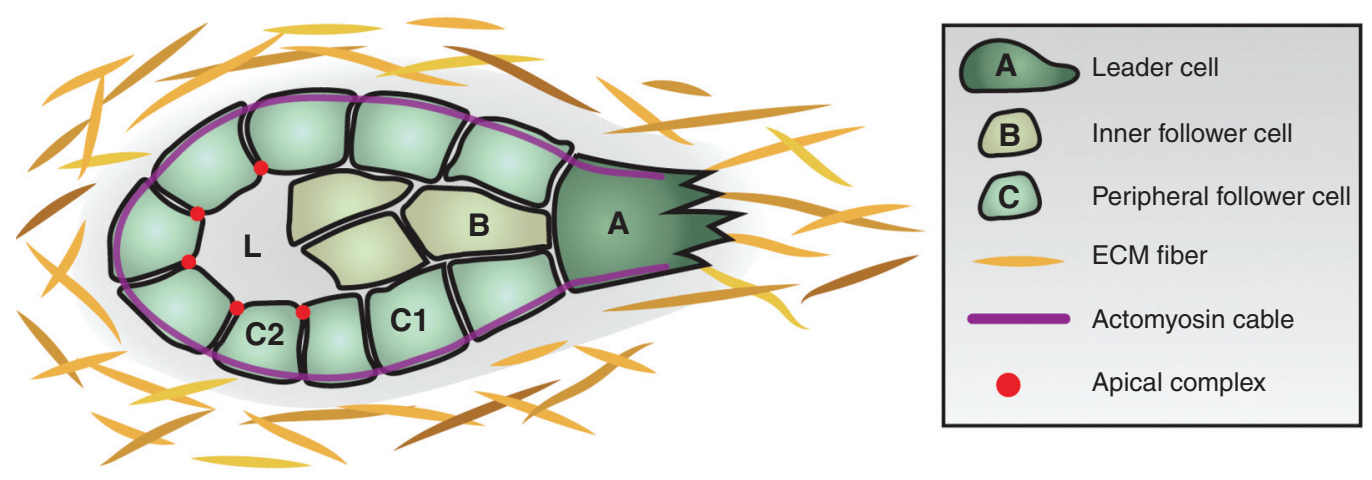

Figure 2. Topological terminology of collective migration. (A) Leader cells comprise one or several cells at the front of the migrating unit, which respond to guidance signals, form protrusions or a leading edge, and determine direction of migration. Leader cells face an asymmetric environment of lateral and rear cell-cell adhesions and extracellular matrix (ECM) at the front, and show cellular front-rear polarity. $(B)$ Inner follower cells are behind leader cells inside of the cluster and lack asymmetric cell-cell adhesions but front-rear polarization may be induced. Migrating cohorts of simple epithelia or endothelia lack inner follower cells. (C) Peripheral follower cells locate at the outside of the cluster and face the ECM on one side, while adhering to other cells on other sides (C1). Peripheral follower cells form actomyosin cables at the outer surface of the cluster. When inner follower cells are absent, peripheral followers (C2) show apicobasal polarization, with an apical domain toward an internal lumen (L). 
2009; Lebreton and Casanova 2014; Yamaguchi et al. 2015). More recent bioengineering approaches have revealed emerging biophysical mechanisms for leader cell induction, which depend on membrane curvature, mechanical compression, and local force generation (Rolli et al. 2012; Tse et al. 2012; Rausch et al. 2013; Yang et al. 2016), possibly through Rho-ROCKdependent mechanisms (Omelchenko et al. 2003; Reffay et al. 2014). Although intrinsic factors contribute to leader cell selection, leader cells are often overtaken and replaced by follower cells, suggesting plasticity in leader cell fate (Poujade et al. 2007; Prasad and Montell 2007; Ewald et al. 2008; Jakobsson et al. 2010). On the other hand, stable epigenetically distinct subpopulations exist in breast cancer cell lines that have a higher propensity to become leader cells (Westcott et al. 2015), but it remains to be determined whether such stable populations result from tumor heterogeneity or reflect a general physiological mechanism.

\section{Leader Cell-Specific Protein Expression}

Specific gene transcription programs promote the fate and function of leader cells. The bestdescribed example of leader cell-specific protein expression involves lateral Delta-Notch inhibitory signaling. RTK-induced expression of Delta/Delta-like-4 (Dll4) in tracheal or endothelial tip cells induces Notch signaling in adjacent cells thereby inhibiting tip cell fate and promoting stalk cell fate (Ghabrial and Krasnow 2006; Hellstrom et al. 2007). Dll4 can also be induced via a mechanism involving the deposition of laminin $\alpha 4$ (Estrach et al. 2011; Stenzel et al. 2011) or by local reduction of mechanical stress in migrating epithelial sheets (Riahi et al. 2015), indicating conserved roles for this pathway in leader cell selection. Proteins promoting leader cell migration include Mipp, NRP1, podoplanin, and fascin, which promote filopodial invasion (Wicki et al. 2006; Vignjevic et al. 2007; Cheng and Andrew 2015; Fantin et al. 2015), whereas elevated expression of $\beta 1$-integrin (Hegerfeldt et al. 2002; Kato et al. 2014; Yamaguchi et al. 2015) promotes migration by enhancing traction on the substrate.
The increase of $\beta 1$-integrin expression in leader cells involves adherens junction-dependent transcriptional regulation via the myocardin-related transcription factor (MRTF) (Kato et al. 2014). MRTF is retained in the cytoplasm by monomeric G-actin, and translocates to the nucleus on a decrease of $\mathrm{G}$-actin resulting from increased actin polymerization. In leader cells, MRTF-B translocates to the nucleus on activation of RhoA, which is induced by the loss of E-cadherin-based junctions. In the nucleus, MRTF-B interacts with Trim27 and up-regulates $\beta 1$-integrin expression by inhibiting the $\beta 1$-integrin-specific miRNA-124 (Kato et al. 2014; Gjorevski et al. 2015). Previous work has implicated MRTFs as cofactor of serum response factor (SRF) in transcriptional regulation of many actin regulators involved in cell migration downstream from Rho GTPases (Olson and Nordheim 2010). It is therefore possible that MRTF-induced $\beta 1$-integrin expression in leader cells acts in a positive feedback loop in which increased Rho GTPase signaling downstream from integrins promotes transcriptional activity of MRTF/SRF, thereby inducing additional leader cell-specific proteins required for migration (Reymond et al. 2012; Hermann et al. 2016).

\section{LEADER CELL FRONT-REAR POLARITY}

In addition to defining the front of a cell collective at the supracellular level, leader cells show intracellular front-rear polarization as well. The asymmetric distribution of cadherin-based adherens junctions resulting from their absence at the front is a distinguishing feature of leader cells and is sufficient to induce front-rear polarization of the cytoskeleton and the cytoplasm in vivo and in vitro (Desai et al. 2009; Dupin et al. 2009; Ozaki et al. 2010; Dumortier et al. 2012; Ng et al.2012; Oubaha et al. 2012; Weber et al.2012).

\section{Cadherin-Dependent Polarization}

The mechanisms that underlie cadherin-dependent front-rear polarization depend on the activity of cdc42, Rac, and PI3K, and the interaction of cell-cell junctions with the actin 


\section{J.-H. Venhuizen and M.M. Zegers}

cytoskeleton (Desai et al. 2009; Ozaki et al. 2010; Dumortier et al. 2012) and appear quite conserved as they were shown in both epithelial and nonepithelial cells, typically downstream from E-cadherin and $\mathrm{N}$-cadherin, respectively. However, detailed analysis of these pathways is complex owing to the fact that many signaling pathways, in particular Rho GTPases, control both front-rear polarity, as discussed previously, and cell-cell adhesion (Fig. 3A1). Briefly, the involvement of Rho GTPases in cell-cell adhesion includes transient Rac activation on

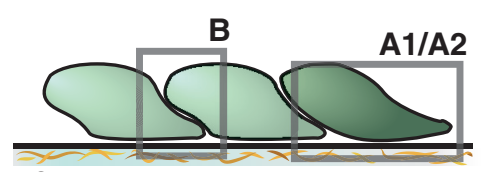

Side view
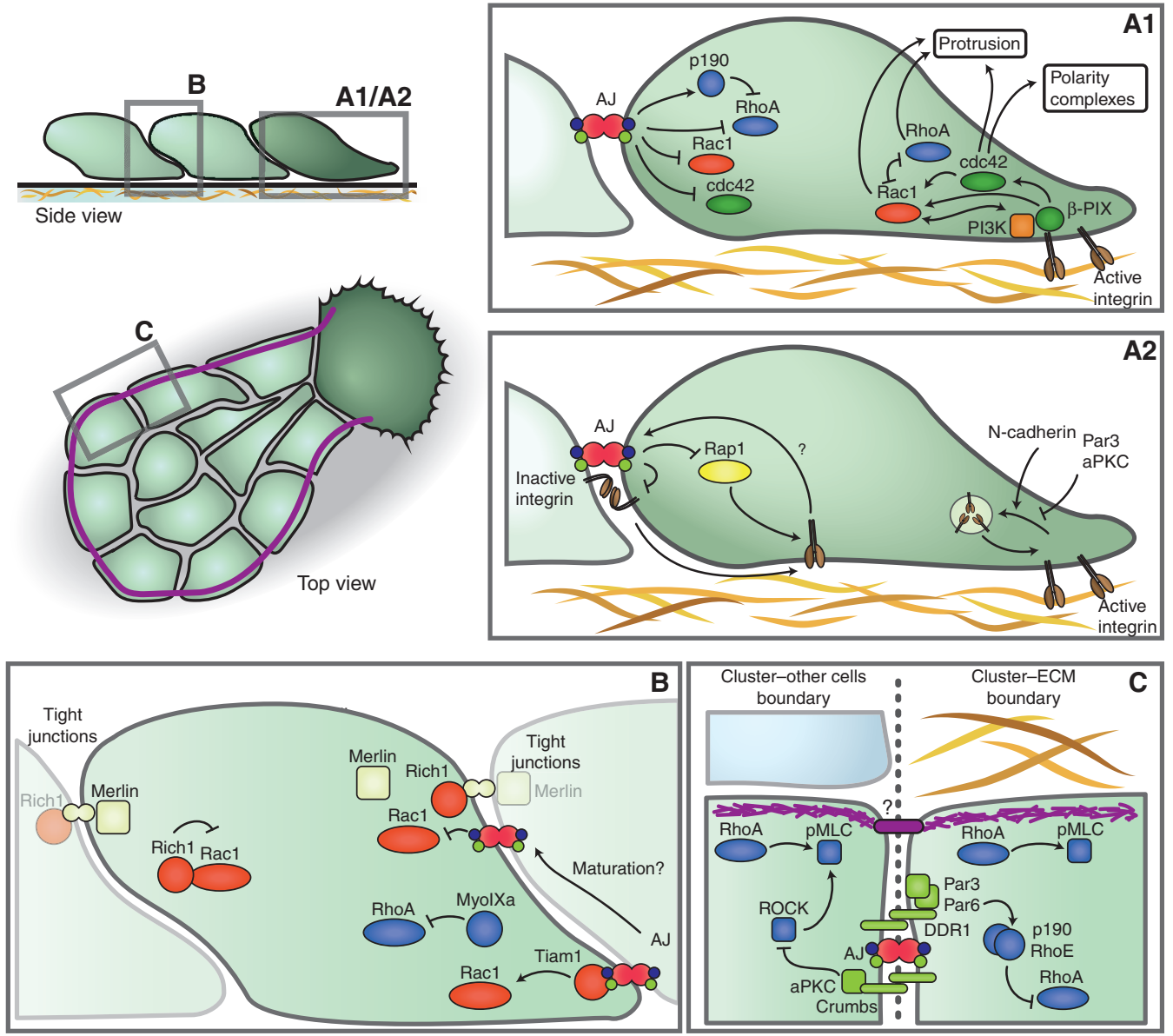

Figure 3. Cell-cell adhesions regulate leader and follower cell polarity. Leader cells are shown in dark green, follower cells in lighter green. See text for details. (A1) Mature adherens junctions (AJs) suppress activity of RhoA, Rac1, and cdc42. Cell-extracellular matrix (ECM) adhesions at the leading edge recruit $\beta$ PIX, resulting in the activation of cdc42, Rac1, and cross talk with PI3K. RhoA also acts at the leading edge. Polarized activity of RhoGTPases causes polarized pseudopodia extension, recruitment of polarity proteins, and reorientation of microtubules. (A2) AJ between leader cell and follower cells sequester and inhibit activation of integrins, leading to preferential activity at the leading edge. (B) Polarized RhoGTPase activity in follower cells. Follower cells extend frontal cryptic lamellipodia underneath anterior cells, where basal nascent AJs promote Racl activity, possibly via Tiam1, and inhibit RhoAvia myosin IXa. Tight junctions at the rear bind Merlin, leaving Rich1 available to inhibit Rac1. At the front, tension on the tight junctions dissociates Merlin and recruits Rich1, leading to derepression of Rac1. (C) Cohesive polarization in peripheral follower cells causes the assembly of a supracellular contractile actomyosin cable. Rho-ROCK signaling is inhibited at internal cell-cell contacts by DDR1, E-cadherin, or Crumbs, leading to activation of myosin light chain and actomyosin at the cell periphery. 
formation of nascent adherens junctions, which drives lateral junction expansion through actin polymerization (Fukuyama et al. 2006; Yamada and Nelson 2007). Junctions mature by Rhodependent actomyosin contraction (Yamada and Nelson 2007; Cavey and Lecuit 2009) and maintenance and dynamics of established adherens junctions continue to depend on both Rac and Rho activity, which likely act at lower and subregional levels (Ratheesh and Yap 2012). Front-rear polarization thus requires cross talk between cell-cell adhesions and cell-ECM adhesions. An example of cross talk involving a $\beta$ catenin-aPKC complex has been observed during endothelial sprouting. On angiopoietin-1 stimulation, this complex localizes to both the cell front to activate Rac, and to the rear, where it stabilizes cell-cell adhesion, and thus promotes both front-rear polarization and cohesion of the migrating branch (Oubaha et al. 2012). Other examples involve Tiam 1 and $\beta$ PIX, which activate Rac/cdc42 at the leading edge downstream from integrins, but can also be recruited to adherens junctions (Sander et al. 1998; Zegers et al. 2003; Audebert et al. 2004), thereby depleting them locally from cell-ECM adhesions, and potentially leading to preferential GEF activity at the leading edge. Indeed, experimentally induced retention of $\beta$ PIX in cellECM adhesions increases collective migration in $3 \mathrm{D}$ culture through mechanisms that depend on sustained PI3K and Rac signaling (Zegers et al. 2003; Hunter and Zegers 2010; Liu et al. 2010a). In mesenchymal leader cells, recruitment of $\beta$ PIX to adherens junctions by P-cadherin promotes cell polarization through a cdc42-dependent increase in both tensional forces at cell-cell adhesions and traction forces at cell-ECM adhesions (Plutoni et al. 2016). Although the exact mechanism of these altered forces observed in this study were not clear, others have found that $\beta$ PIX is inactivated at the cell rear of single cells owing to its interaction with actomyosin (Vicente-Manzanares et al. 2011), which may suggest important mechanosensitive roles of $\beta$ PIX in modulating outcomes of both Rho and Rac signaling.

Integrin-based cell-ECM adhesions preferentially localize to the front (Fig. 3A2). This localization can be regulated by adherens junction components through various mechanisms. Suppression of cell-ECM adhesions near cellcell junctions can be caused by down-regulation of Rac activity (Yamada and Nelson 2007) or by sequestering main components at cell-cell adhesions, such as vinculin (le Duc et al. 2010; Bays et al. 2014) or $\alpha 5$-integrin (Lefort et al. 2011). Furthermore, adherens junctions inhibit the activation of integrins through p120 (Ouyang et al. 2013; Julich et al. 2015) or by repressing the integrin activator Rap1 (Balzac et al. 2005). Assembly of nascent cell-ECM adhesions at the cell front mainly depends on delivery of integrins by vesicular traffic (ShafaqZadah et al. 2016). Several proteins that function at cell-cell adhesions have been shown to regulate integrin trafficking at the leading edge. This includes Par3 and aPKC, which prevent integrin endocytosis by inhibiting Numb (Nishimura and Kaibuchi 2007), and leading edge-associated $\mathrm{N}$-cadherin, which promotes Rab5-dependent macropinocytosis of integrins (Camand et al. 2012; Wen et al. 2016).

Both integrin-based cell-ECM adhesions and cadherin-based cell-cell adhesions are mechanosensitive structures (Ladoux et al. 2016). The preferential assembly of cell-ECM adhesions at the leading edge is reinforced by traction forces on the ECM, which depend on the stiffness of the substrate (Trichet et al. 2012). In addition, cadherin-based junctions are under constant tension (Borghi et al. 2012) and orient traction on the ECM toward the periphery of the cells (Mertz et al. 2013), likely through a mechanism that relies on internal force balancing between cell-cell and cell-ECM adhesions. Conversely, increased traction forces from the ECM enhances cell-cell adhesion (Liu et al. 2010b; Bays et al. 2014). This force-dependent cross talk between cell-cell and cell-ECM adhesions causes actomyosin to accumulate near cell-cell adhesions and induces front-rear polarization of leader cells and increases the persistence of collective migration ( $\mathrm{Ng}$ et al. 2012; Weber et al. 2012; Plutoni et al. 2016). The correlation of Ecadherin-dependent tension anisotropy with directional migration was shown in border cells expressing a tension-sensitive E-cadherin FRET 
probe, which showed a gradient of tension across cell-cell junctions that was higher at the leading edge, and required for directionality of the cluster (Cai et al. 2014). In summary, cell-cell and cell-ECM adhesions regulate each other through various mechanisms, including tension, thereby promoting front-rear polarization and directional migration.

\section{Specificity of Cadherin Family Proteins}

Cadherin interference experiments in cells expressing a single predominant classical cadherin (Dupin et al. 2009) or with dominantnegative E-cadherin (Desai et al. 2009), which down-regulates most classical cadherins (Liu et al. 2010a), indicate that cadherins control collective migration by redundant mechanisms. This notion, however, has been challenged by several recent studies. For example, leader cell polarity in myoblasts depends on cdc42 activation mediated by recruitment of $\beta$ PIX by P-cadherin, but not E- or R-cadherin (Plutoni et al. 2016). Likewise, recruitment of $\beta$ PIX by cadherin-6, but not E-cadherin, and associated inhibition of PI3K, likely underlies the cadherin-dependent inhibition of collective migration in a 3D epithelial model (Yu et al. 2003; Jia et al. 2011). Cadherin family member-specific roles in collective migration may be explained by differential sensitivity to mechanical signals. Indeed, when coexpressed, E-cadherin, but not $\mathrm{P}$-cadherin, is able to dynamically reinforce cell adhesion on applied force and preferentially recruits vinculin, whereas P-cadherin is associated with a gradual time-resolved increase of junctional tension in migrating sheets, likely independent of vinculin (Bazellieres et al. 2015).

Roles of Other Cell-Cell Adhesions in Front-Rear Polarization

Components of other cell-cell adhesion complexes can also contribute to leader cell polarization. Tight junctions provide a seal between apical and basal epithelial membrane domains, but some of their principal components localize to the leading edge to regulate protrusion. For instance, ZO-1 promotes formation of a single lamellipodium by locally inhibiting $\mathrm{Rac}$ through a $\mathrm{PKC} \varepsilon$-dependent interaction with $\alpha 5$-integrins (Tuomi et al. 2009), whereas downstream from cdc42, it regulates migration via MRCK- $\beta$ (Huo et al. 2011). Furthermore, the tight junction protein occludin promotes Rac activation by recruiting $\mathrm{PI} 3 \mathrm{~K}$ and orients the MTOC by recruiting aPKC and Par3 (Du et al. 2010). Gap junctions, which form connexin-based intercellular channels, promote collective migration by sensitizing cell cohorts to shallow chemoattractive gradients (Ellison et al. 2016) and control front-rear polarization by channel-independent mechanisms that rely on the ability of connexin43 to organize the cytoskeleton (Xu et al. 2006; Rhee et al. 2009; Francis et al. 2011). It is likely that front-rear polarization mechanisms downstream from these adhesions are tightly integrated with cadherin-dependent pathways, but the details of such integration are still lacking.

\section{FRONT-REAR POLARIZATION OF INNER FOLLOWER CELLS}

Inner follower cells lack the front-rear asymmetry of adherens junctions and, as previously discussed, rely on leader cell-derived cues for directional migration. Although in vivo these cues may involve self-generated chemotactic gradients (Dona et al. 2013; Dalle Nogare et al. 2014; Muinonen-Martin et al. 2014), reductionist $2 \mathrm{D}$ models have shown that cadherin-based cell-cell adhesion is sufficient to orient follower cell migration, and controls migrational persistence (Cai et al. 2014) and velocity correlation in migrating collectives (Arboleda-Estudillo et al. 2010; Petitjean et al. 2010; Doxzen et al. 2013; Garcia et al. 2015; Plutoni et al. 2016). The distinct requirements for directional cues in leader and follower cells were emphasized in an unbiased siRNA-based screen for regulators of emergent behavior of FGF-induced endothelial sheet migration (Vitorino and Meyer 2008). Although both leader and follower cells require actin regulators, such as $\operatorname{Rac}$ and $\operatorname{Arp} 2 / 3$ for forward movement, directed migration in leader cells is driven by regulators of FGF signaling, 
whereas orientation of trailing cells depends on cadherin-associated proteins. These findings thus correlate with the crucial roles for cadherins in follower cell polarity and with earlier studies showing that follower cells can actively migrate using similar mechanisms as leader cells, including a dependence on Rac activation (Fenteany et al. 2000; Farooqui and Fenteany 2005).

Cadherin-dependent directional migration of follower cells is guided by mechanical coupling, likely achieved via cell-cell-associated actomyosin (Zegers and Friedl 2014). Traction forces of leader cells are not sufficient to drag all follower cells forward (Haas and Gilmour 2006; Trepat et al. 2009; Tambe et al. 2011) and migration of followers likely depends on both tensional forces from cell-cell junctions from anterior cells and on traction forces from contractile actomyosin in follower cells resulting from cell-ECM adhesion (Trepat et al. 2009; Tambe et al. 2011; Vitorino et al. 2011). Front-rear polarization of follower cells on 2D surfaces is associated with Rac-dependent frontal actin protrusions named cryptic lamellipodia that underlap cells at their anterior (Fig. 3B) (Farooqui and Fenteany 2005; Omelchenko and Hall 2012). The presence of these cryptic lamellipodia, which may contribute to migration by increasing traction, suggests that follower cells can polarize Rac activity toward the front. Different possible mechanisms controlling frontal Rac activation are emerging. First, differential interactions of Tiam-1 with Par3 at tight junctions and $\beta 2$ syntrophin at subapical regions control an apicobasal gradient of Racl activity in polarized epithelia, leading to high basal Rac activity (Mack et al. 2012), which may facilitate formation of cryptic lamellipodia. Rac activation near the basal surface may be further promoted by a high turnover rate of cadherins in cryptic lamellipodia (Kametani and Takeichi 2007) and subsequent Tiam-dependent activation of Rac at nascent adherens junctions (Malliri et al. 2004; Yamada and Nelson 2007). Additional mechanisms controlling an intracellular Rac gradient may come from tensional forces on tight junctions derived from leader cells, which dissociates the tumor suppressor merlin from tight junctions. As merlin competes for tight junction binding with the Rac1GAP Rich1, this leads to sequestration of Rich1 to tight junctions, resulting in activation of Rac at the cell front (Das et al. 2015). Finally, the RhoGAP Myosin IXa is recruited to nascent adherens junctions and cryptic lamellipodia where it inhibits Rho (Omelchenko and Hall 2012), suggesting that Rho as well shows a front-rear gradient. Thus, it appears that integrated forces from cell-cell and cell-ECM contacts provide long-range directional cues to control polarization of follower cells; information on the molecular sensors that act downstream from these cues is still scant.

\section{POLARIZATION OF PERIPHERAL FOLLOWER CELLS}

Even though, similarly to leader cells, peripheral follower cells face an asymmetric environment of ECM and cell-cell adhesions, they do not form outward protrusions and, like inner follower cells, depend on leader cell-derived cues for front-rear polarization. In many in vitro and in vivo systems peripheral follower cells assemble supracellular actomyosin cables at their outward-facing membrane domain (Figs. 2,3C) (Jacinto et al. 2001; Hidalgo-Carcedo et al. 2011; Lucas et al. 2013; Roper 2013; Reffay et al. 2014; Ravasio et al. 2015). These actomyosin cables serve different functions during tissue-level movements during embryonic development and wound healing (Jacinto et al. 2001; Roper 2013). Supracellular actomyosin cables start in the leader cell (Rausch et al. 2013) and extend along the periphery of the collective. Ablating this cable leads to recoil, indicating that it is under tension, and causes the formation of lamellipodia from peripheral follower cells (Reffay et al. 2014). Ectopic leader cells are also induced in border cell clusters on inhibition of linkage of cortical actin to the plasma membrane by interfering with moesin function (Ramel et al. 2013). The polarized formation of actomyosin cables at the cell periphery appears to be mainly regulated by local inhibition of ROCK signaling by cell-cell adhesions. In cancer cell collectives this depends on Par3 and 
Par6, which are recruited to cell-cell junctions by E-cadherin and discoidin domain receptor 1 , and inhibit Rho-ROCK signaling via RhoE (Wennerberg et al. 2003; Hidalgo-Carcedo et al. 2011), whereas ROCK activity at internal cell-cell contacts in the developing Drosophila salivary gland is inhibited by aPKC, recruited by Crumbs (Fig. 3C) (Roper 2012). Cadherins may also inhibit Rho by recruiting p190RhoGAP, via p120 (Wildenberg et al. 2006). Similar mechanisms may apply to border cell migration, where the cluster does not contact ECM, but instead contacts nurse cells at the cluster periphery. As nurse cells express less E-cadherin (Cai et al. 2014), it is possible that the density of cell adhesion clusters, and thus RhoA inhibition, is lower at these contacts, leading to actomyosin accumulation. Thus, inhibition of RhoA signaling at cell-cell contacts causes the polarized assembly of contractile actomyosin at the cluster periphery. This assembly of actomyosin cables thus comprises a distinct type of "cohesive cell polarization" in peripheral follower cells that serves to mechanically link leader cells to peripheral follower cells, inhibit leader cell behavior in these cells, and to maintain cohesion of the migrating cluster.

\section{CONCLUDING REMARKS}

As with any good teamwork, collective cell migration involves a cohesive group of which the efficacy is more than the sum of its parts, and to fully comprehend the process we must understand both the individual parts and the ways they interact and collaborate. Research over the past years has provided important insights on both ends. At the level of individual cells, leader cells are best understood, as they share many basic mechanisms of front-rear polarization with single migrating cells, which have been studied in considerable detail. Adherens junctions between leader cells and follower cells provide a powerful polarizing cue for leader cells, and follower cells are thus not only following, but actively participating, in steering the leader cell. We know much less about how follower cells generate intrinsic front-rear polarity. Inner follower cells depend on leader cells for direction, through mechanocoupling, but the central mechanosensors that control downstream front-rear polarization are still largely undefined. Spherical lumen-containing cysts of epithelial cells in 3D culture rotate persistently (Tanner et al. 2012). These movements can be considered collective migration without leader cells, and potentially provide a suitable model to investigate follower cell polarity and directional migration. Peripheral follower cells maintain cohesion of the collective through actomyosin cables and their nature is still quite elusive. For instance, it is unclear if they also show front-rear polarization.

Although the functions of different cells within collectives diverge, they all depend on cell-cell adhesion-regulated polarity for their function in collective migration. Even in nonmoving epithelia, stable cell-cell adhesion depends on continuous remodeling and turnover of adherens junctions (Wirtz-Peitz and Zallen 2009) and subregional dynamics of cadherins is expected to have crucial roles in controlling collective migration. Indeed, cadherins show a basal-to-apical flow in migrating follower cells but not in stationary cells (Kametani and Takeichi 2007), whereas a front-to-back gradient of p120-dependent endocytosis of N-cadherin controls cadherin treadmilling in leader cells (Peglion et al. 2014) showing polarized dynamics of adherens junctions. It will be interesting to obtain deeper insight on how modulators of cadherin dynamics compartmentalize and direct the migrating cluster.

\section{ACKNOWLEDGMENTS}

The authors thank Antoine Khalil, Sjoerd van Helvert, and Martin ter Beest for helpful comments.

\section{REFERENCES}

Affolter M, Caussinus E. 2008. Tracheal branching morphogenesis in Drosophila: New insights into cell behaviour and organ architecture. Development 135: 2055-2064.

Arboleda-Estudillo Y, Krieg M, Stuhmer J, Licata NA, Muller DJ, Heisenberg CP. 2010. Movement directionality in 
collective migration of germ layer progenitors. Curr Biol 20: $161-169$.

Audebert S, Navarro C, Nourry C, Chasserot-Golaz S, Lecine P, Bellaiche Y, Dupont JL, Premont RT, Sempere C, Strub JM, et al. 2004. Mammalian Scribble forms a tight complex with the $\beta$ PIX exchange factor. Curr Biol 14: 987-995.

Balzac F, Avolio M, Degani S, Kaverina I, Torti M, Silengo L, Small JV, Retta SF. 2005. E-cadherin endocytosis regulates the activity of Rap1: A traffic light GTPase at the crossroads between cadherin and integrin function. J Cell Sci 118: $4765-4783$.

Bays JL, Peng X, Tolbert CE, Guilluy C, Angell AE, Pan Y, Superfine R, Burridge K, DeMali KA. 2014. Vinculin phosphorylation differentially regulates mechanotransduction at cell-cell and cell-matrix adhesions. J Cell Biol 205: 251-263.

Bazellieres E, Conte V, Elosegui-Artola A, Serra-Picamal X, Bintanel-Morcillo M, Roca-Cusachs P, Munoz JJ, SalesPardo M, Guimera R, Trepat X. 2015. Control of cell-cell forces and collective cell dynamics by the intercellular adhesome. Nat Cell Biol 17: 409-420.

Borghi N, Sorokina M, Shcherbakova OG, Weis WI, Pruitt BL, Nelson WJ, Dunn AR. 2012. E-cadherin is under constitutive actomyosin-generated tension that is increased at cell-cell contacts upon externally applied stretch. Proc Natl Acad Sci 109: 12568-12573.

Bravo-Cordero JJ, Magalhaes MA, Eddy RJ, Hodgson L, Condeelis J. 2013. Functions of cofilin in cell locomotion and invasion. Nat Rev Mol Cell Biol 14: 405-417.

Cai D, Chen SC, Prasad M, He L, Wang X, Choesmel-Cadamuro V, Sawyer JK, Danuser G, Montell DJ. 2014. Mechanical feedback through E-cadherin promotes direction sensing during collective cell migration. Cell 157: 1146-1159.

Camand E, Peglion F, Osmani N, Sanson M, Etienne-Manneville S. 2012. N-cadherin expression level modulates integrin-mediated polarity and strongly impacts on the speed and directionality of glial cell migration. J Cell Sci 125: 844-857.

Campa CC, Ciraolo E, Ghigo A, Germena G, Hirsch E. 2015. Crossroads of PI3K and Rac pathways. Small GTPases 6: $71-80$.

Cavey M, Lecuit T. 2009. Molecular bases of cell-cell junctions stability and dynamics. Cold Spring Harb Perspect Biol 1: a002998.

Cheng YL, Andrew DJ. 2015. Extracellular Mipp1 activity confers migratory advantage to epithelial cells during collective migration. Cell Rep 13: 2174-2188.

Chi X, Michos O, Shakya R, Riccio P, Enomoto H, Licht JD, Asai N, Takahashi M, Ohgami N, Kato M, et al. 2009. Retdependent cell rearrangements in the Wolffian duct epithelium initiate ureteric bud morphogenesis. Dev Cell 17: 199-209.

Costantini F. 2006. Renal branching morphogenesis: Concepts, questions, and recent advances. Differentiation 74: $402-421$.

Dalle Nogare D, Somers K, Rao S, Matsuda M, ReichmanFried M, Raz E, Chitnis AB. 2014. Leading and trailing cells cooperate in collective migration of the zebrafish posterior lateral line primordium. Development 141: 3188-3196.
Das T, Safferling K, Rausch S, Grabe N, Boehm H, Spatz JP. 2015. A molecular mechanotransduction pathway regulates collective migration of epithelial cells. Nat Cell Biol 17: 276-287.

Desai RA, Gao L, Raghavan S, Liu WF, Chen CS. 2009. Cell polarity triggered by cell-cell adhesion via E-cadherin. $J$ Cell Sci 122: 905-911.

Dona E, Barry JD, Valentin G, Quirin C, Khmelinskii A, Kunze A, Durdu S, Newton LR, Fernandez-Minan A, Huber W, et al. 2013. Directional tissue migration through a self-generated chemokine gradient. Nature 503: $285-289$.

Doxzen K, Vedula SR, Leong MC, Hirata H, Gov NS, Kabla AJ, Ladoux B, Lim CT. 2013. Guidance of collective cell migration by substrate geometry. Integr Biol (Camb) 5: $1026-1035$.

Du D, Xu F, Yu L, Zhang C, Lu X, Yuan H, Huang Q, Zhang F, Bao H, Jia L, et al. 2010. The tight junction protein, occludin, regulates the directional migration of epithelial cells. Dev Cell 18: 52-63.

Dumortier JG, Martin S, Meyer D, Rosa FM, David NB. 2012. Collective mesendoderm migration relies on an intrinsic directionality signal transmitted through cell contacts. Proc Natl Acad Sci 109: 16945-16950.

Dupin I, Camand E, Etienne-Manneville S. 2009. Classical cadherins control nucleus and centrosome position and cell polarity. J Cell Biol 185: 779-786.

Ellenbroek SI, Iden S, Collard JG. 2012. The Rac activator Tiaml is required for polarized protrusional outgrowth of primary astrocytes by affecting the organization of the microtubule network. Small GTPases 3: 4-14.

Ellison D, Mugler A, Brennan MD, Lee SH, Huebner RJ, Shamir ER, Woo LA, Kim J, Amar P, Nemenman I, et al. 2016. Cell-cell communication enhances the capacity of cell ensembles to sense shallow gradients during morphogenesis. Proc Natl Acad Sci 113: E679-E688.

Estrach S, Cailleteau L, Franco CA, Gerhardt H, Stefani C, Lemichez E, Gagnoux-Palacios L, Meneguzzi G, Mettouchi A. 2011. Laminin-binding integrins induce Dll4 expression and Notch signaling in endothelial cells. Circ Res 109: $172-182$.

Etienne-Manneville S, Hall A. 2003. Cdc42 regulates GSK$3 \beta$ and adenomatous polyposis coli to control cell polarity. Nature 421: 753-756.

Ewald AJ, Brenot A, Duong M, Chan BS, Werb Z. 2008. Collective epithelial migration and cell rearrangements drive mammary branching morphogenesis. Dev Cell 14: 570-581.

Ewald AJ, Huebner RJ, Palsdottir H, Lee JK, Perez MJ, Jorgens DM, Tauscher AN, Cheung KJ, Werb Z, Auer M. 2012. Mammary collective cell migration involves transient loss of epithelial features and individual cell migration within the epithelium. J Cell Sci 125: 2638-2654.

Fantin A, Lampropoulou A, Gestri G, Raimondi C, Senatore V, Zachary I, Ruhrberg C. 2015. NRP1 Regulates CDC42 activation to promote filopodia formation in endothelial tip cells. Cell Rep 11: 1577-1590.

Farooqui R, Fenteany G. 2005. Multiple rows of cells behind an epithelial wound edge extend cryptic lamellipodia to collectively drive cell-sheet movement. J Cell Sci 118: 5163. 
J.-H. Venhuizen and M.M. Zegers

Fenteany G, Janmey PA, Stossel TP. 2000. Signaling pathways and cell mechanics involved in wound closure by epithelial cell sheets. Curr Biol 10: 831-838.

Francis R, Xu X, Park H, Wei C-J, Chang S, Chatterjee B, Lo C. 2011. Connexin 43 modulates cell polarity and directional cell migration by regulating microtubule dynamics. PloS ONE 6: e26379.

Friedl P, Gilmour D. 2009. Collective cell migration in morphogenesis, regeneration and cancer. Nat Rev Mol Cell Biol 10: 445-457.

Fukuyama T, Ogita H, Kawakatsu T, Inagaki M, Takai Y. 2006. Activation of Rac by cadherin through the c-SrcRap1-phosphatidylinositol 3-kinase-Vav2 pathway. Oncogene 25: 8-19.

Gaggioli C, Hooper S, Hidalgo-Carcedo C, Grosse R, Marshall JF, Harrington K, Sahai E. 2007. Fibroblast-led collective invasion of carcinoma cells with differing roles for RhoGTPases in leading and following cells. Nat Cell Biol 9: $1392-1400$.

Garcia S, Hannezo E, Elgeti J, Joanny J-F, Silberzan P, Gov NS. 2015. Physics of active jamming during collective cellular motion in a monolayer. Proc Natl Acad Sci 112: 15314-15319.

Ghabrial AS, Krasnow MA. 2006. Social interactions among epithelial cells during tracheal branching morphogenesis. Nature 441: 746-749.

Gjorevski N, A SP, Varner VD, Nelson CM. 2015. Dynamic tensile forces drive collective cell migration through three-dimensional extracellular matrices. Sci Rep 5: 11458 .

Goicoechea SM, Awadia S, Garcia-Mata R. 2014. I'm coming to GEF you: Regulation of RhoGEFs during cell migration. Cell Adh Migr 8: 535-549.

Gray RS, Cheung KJ, Ewald AJ. 2010. Cellular mechanisms regulating epithelial morphogenesis and cancer invasion. Curr Opin Cell Biol 22: 640-650.

Haas P, Gilmour D. 2006. Chemokine signaling mediates self-organizing tissue migration in the zebrafish lateral line. Dev Cell 10: 673-680.

Haeger A, Wolf K, Zegers MM, Friedl P. 2015. Collective cell migration: Guidance principles and hierarchies. Trends Cell Biol 25: 556-566.

Hegerfeldt Y, Tusch M, Brocker EB, Friedl P. 2002. Collective cell movement in primary melanoma explants: Plasticity of cell-cell interaction, $\beta 1$-integrin function, and migration strategies. Cancer Res 62: 2125-2130.

Hellstrom M, Phng LK, Hofmann JJ, Wallgard E, Coultas L, Lindblom P, Alva J, Nilsson AK, Karlsson L, Gaiano N, et al. 2007. Dll4 signalling through Notch1 regulates formation of tip cells during angiogenesis. Nature 445: 776780.

Hermann MR, Jakobson M, Colo GP, Rognoni E, Jakobson M, Kupatt C, Posern G, Fassler R. 2016. Integrins synergise to induce expression of the MRTF-A-SRF target gene ISG15 for promoting cancer cell invasion. J Cell Sci 129: 1391-1403.

Hidalgo-Carcedo C, Hooper S, Chaudhry SI, Williamson P, Harrington K, Leitinger B, Sahai E. 2011. Collective cell migration requires suppression of actomyosin at cell-cell contacts mediated by DDR1 and the cell polarity regulators Par3 and Par6. Nat Cell Biol 13: 49-58.
Hunter MP, Zegers MM. 2010. Pak1 regulates branching morphogenesis in 3D MDCK cell culture by a PIX and B1-integrin-dependent mechanism. Am J Physiol Cell Physiol 299: C21-C32.

Huo L, Wen W, Wang R, Kam C, Xia J, Feng W, Zhang M. 2011. Cdc42-dependent formation of the ZO-1/MRCK $\beta$ complex at the leading edge controls cell migration. EMBO J 30: 665-678.

Huttenlocher A, Horwitz AR. 2011. Integrins in cell migration. Cold Spring Harb Perspect Biol 3: a005074.

Jacinto A, Martinez-Arias A, Martin P. 2001. Mechanisms of epithelial fusion and repair. Nat Cell Biol 3: E117-E123.

Jakobsson L, Franco CA, Bentley K, Collins RT, Ponsioen B, Aspalter IM, Rosewell I, Busse M, Thurston G, Medvinsky A, et al. 2010. Endothelial cells dynamically compete for the tip cell position during angiogenic sprouting. Nat Cell Biol 12: 943-953.

Jia L, Liu F, Hansen SH, Ter Beest MB, Zegers MM. 2011. Distinct roles of cadherin-6 and E-cadherin in tubulogenesis and lumen formation. Mol Biol Cell 22: 20312041.

Julich D, Cobb G, Melo AM, McMillen P, Lawton AK, Mochrie SG, Rhoades E, Holley SA. 2015. Cross-scale integrin regulation organizes ECM and tissue topology. Dev Cell 34: 33-44.

Kametani Y, Takeichi M. 2007. Basal-to-apical cadherin flow at cell junctions. Nat Cell Biol 9: 92-98.

Kato T, Enomoto A, Watanabe T, Haga H, Ishida S, Kondo Y, Furukawa K, Urano T, Mii S, Weng L, et al. 2014. TRIM27/MRTF-B-dependent integrin $\beta 1$ expression defines leading cells in cancer cell collectives. Cell Rep 7: $1156-1167$.

Khalil AA, Friedl P. 2010. Determinants of leader cells in collective cell migration. Integr Biol (Camb) 2: 568-574.

Kitamura T, Kometani K, Hashida H, Matsunaga A, Miyoshi H, Hosogi H, Aoki M, Oshima M, Hattori M, Takabayashi A, et al. 2007. SMAD4-deficient intestinal tumors recruit CCR $1^{+}$myeloid cells that promote invasion. Nat Genet 39: 467-475.

Knudsen KA, Wheelock MJ. 2005. Cadherins and the mammary gland. J Cell Biochem 95: 488-496.

Ladoux B, Mege RM, Trepat X. 2016. Front-rear polarization by mechanical cues: From single cells to tissues. Trends Cell Biol 26: 420-433.

Lebreton G, Casanova J. 2014. Specification of leading and trailing cell features during collective migration in the Drosophila trachea. J Cell Sci 127: 465-474.

le Duc Q, Shi Q, Blonk A, Wang N, Leckband D, de Rooij J. 2010. Vinculin potentiates E-cadherin mechanosensing and is recruited to actin-anchored sites within adherens junctions in a myosin II-dependent manner. J Cell Biol 189: $1107-1115$.

Lee CY, Bautch VL. 2011. Ups and downs of guided vessel sprouting: The role of polarity. Physiology (Bethesda) 26: 326-333.

Lefort CT, Wojciechowski K, Hocking DC. 2011. N-cadherin cell-cell adhesion complexes are regulated by fibronectin matrix assembly. J Biol Chem 286: 31493160.

Li J, Jia Z, Kong J, Zhang F, Fang S, Li X, Li W, Yang X, Luo Y, Lin B, Liu T. 2016. Carcinoma-associated fibroblasts lead 
the invasion of salivary gland adenoid cystic carcinoma cells by creating an invasive track. PLoS ONE 11: e0150247.

Liu F, Jia L, Thompson-Baine A, Puglise JM, ter Beest MB, Zegers MM. 2010a. Cadherins and Pak1 control contact inhibition of proliferation by Pak1- $\beta$ PIX-complex dependent regulation of cell-matrix signaling. Mol Cell Biol 30: 1771-1783.

Liu Z, Tan JL, Cohen DM, Yang MT, Sniadecki NJ, Ruiz SA, Nelson CM, Chen CS. 2010b. Mechanical tugging force regulates the size of cell-cell junctions. Proc Natl Acad Sci 107: 9944-9949.

Lucas EP, Khanal I, Gaspar P, Fletcher GC, Polesello C, Tapon N, Thompson BJ. 2013. The Hippo pathway polarizes the actin cytoskeleton during collective migration of Drosophila border cells. J Cell Biol 201: 875-885.

Machacek M, Hodgson L, Welch C, Elliott H, Pertz O, Nalbant P, Abell A, Johnson GL, Hahn KM, Danuser G. 2009. Coordination of Rho GTPase activities during cell protrusion. Nature 461: 99-103.

Mack NA, Porter AP, Whalley HJ, Schwarz JP, Jones RC, Khaja AS, Bjartell A, Anderson KI, Malliri A. 2012. $\beta 2$ syntrophin and Par-3 promote an apicobasal Rac activity gradient at cell-cell junctions by differentially regulating Tiam1 activity. Nat Cell Biol 14: 1169-1180.

Malliri A, van Es S, Huveneers S, Collard JG. 2004. The Rac exchange factor Tiaml is required for the establishment and maintenance of cadherin-based adhesions. J Biol Chem 279: 30092-30098.

Mertz AF, Che Y, Banerjee S, Goldstein JM, Rosowski KA, Revilla SF, Niessen CM, Marchetti MC, Dufresne ER, Horsley V. 2013. Cadherin-based intercellular adhesions organize epithelial cell-matrix traction forces. Proc Natl Acad Sci 110: 842-847.

Mili S, Moissoglu K, Macara IG. 2008. Genome-wide screen reveals APC-associated RNAs enriched in cell protrusions. Nature 453: 115-119.

Muinonen-Martin AJ, Susanto O, Zhang Q, Smethurst E, Faller WJ, Veltman DM, Kalna G, Lindsay C, Bennett DC, Sansom OJ, et al. 2014. Melanoma cells break down LPA to establish local gradients that drive chemotactic dispersal. PLoS Biol 12: e1001966.

Nelson WJ. 2009. Remodeling epithelial cell organization: Transitions between front-rear and apical-basal polarity. Cold Spring Harb Perspect Biol 1: a000513.

Ng MR, Besser A, Danuser G, Brugge JS. 2012. Substrate stiffness regulates cadherin-dependent collective migration through myosin-II contractility. J Cell Biol 199: 545563.

Nguyen-Ngoc KV, Shamir ER, Huebner RJ, Beck JN, Cheung KJ, Ewald AJ. 2015. 3D culture assays of murine mammary branching morphogenesis and epithelial invasion. Methods Mol Biol 1189: 135-162.

Niewiadomska P, Godt D, Tepass U. 1999. DE-cadherin is required for intercellular motility during Drosophila oogenesis. J Cell Biol 144: 533-547.

Nishimura T, Kaibuchi K. 2007. Numb controls integrin endocytosis for directional cell migration with aPKC and PAR-3. Dev Cell 13: 15-28.

Nishimura T, Yamaguchi T, Kato K, Yoshizawa M, Nabeshima Y, Ohno S, Hoshino M, Kaibuchi K. 2005.
PAR-6-PAR-3 mediates Cdc42-induced Rac activation through the Rac GEFs STEF/Tiam1. Nat Cell Biol 7: $270-277$.

Ochoa-Espinosa A, Affolter M. 2012. Branching morphogenesis: From cells to organs and back. Cold Spring Harb Perspect Biol 4: a008243.

Olson EN, Nordheim A. 2010. Linking actin dynamics and gene transcription to drive cellular motile functions. Nat Rev Mol Cell Biol 11: 353-365.

Omelchenko T, Hall A. 2012. Myosin-IXA regulates collective epithelial cell migration by targeting RhoGAP activity to cell-cell junctions. Curr Biol 22: 278-288.

Omelchenko T, Fetisova E, Ivanova O, Bonder EM, Feder H, Vasiliev JM, Gelfand IM. 2001. Contact interactions between epitheliocytes and fibroblasts: Formation of heterotypic cadherin-containing adhesion sites is accompanied by local cytoskeletal reorganization. Proc Natl Acad Sci 98: 8632-8637.

Omelchenko T, Vasiliev JM, Gelfand IM, Feder HH, Bonder EM. 2003. Rho-dependent formation of epithelial "leader" cells during wound healing. Proc Natl Acad Sci 100: 10788-10793.

Osmani N, Peglion F, Chavrier P, Etienne-Manneville S. 2010. Cdc42 localization and cell polarity depend on membrane traffic. J Cell Biol 191: 1261-1269.

Oubaha M, Lin MI, Margaron Y, Filion D, Price EN, Zon LI, Cote JF, Gratton JP. 2012. Formation of a PKC $\zeta / \beta$ catenin complex in endothelial cells promotes angiopoietin-1-induced collective directional migration and angiogenic sprouting. Blood 120: 3371-3381.

Ouyang M, Lu S, Kim T, Chen CE, Seong J, Leckband DE, Wang F, Reynolds AB, Schwartz MA, Wang Y. 2013. Ncadherin regulates spatially polarized signals through distinct p120ctn and $\beta$-catenin-dependent signalling pathways. Nat Commun 4: 1589.

Ozaki C, Yoshioka M, Tominaga S, Osaka Y, Obata S, Suzuki ST. 2010. p120-catenin is essential for N-cadherin-mediated formation of proper junctional structure, thereby establishing cell polarity in epithelial cells. Cell Struct Funct 35: 81-94.

Palamidessi A, Frittoli E, Garre M, Faretta M, Mione M, Testa I, Diaspro A, Lanzetti L, Scita G, Di Fiore PP. 2008. Endocytic trafficking of Rac is required for the spatial restriction of signaling in cell migration. Cell 134: 135-147.

Peglion F, Llense F, Etienne-Manneville S. 2014. Adherens junction treadmilling during collective migration. Nat Cell Biol 16: 639-651.

Pegtel DM, Ellenbroek SI, Mertens AE, van der Kammen RA, de Rooij J, Collard JG. 2007. The Par-Tiam1 complex controls persistent migration by stabilizing microtubule-dependent front-rear polarity. Curr Biol 17: 1623-1634.

Petitjean L, Reffay M, Grasland-Mongrain E, Poujade M, Ladoux B, Buguin A, Silberzan P. 2010. Velocity fields in a collectively migrating epithelium. Biophys $J$ 98: 1790-1800.

Plutoni C, Bazellieres E, Le Borgne-Rochet M, Comunale F, Brugues A, Seveno M, Planchon D, Thuault S, Morin N, Bodin S, et al. 2016. P-cadherin promotes collective cell migration via a Cdc42-mediated increase in mechanical forces. J Cell Biol 212: 199-217. 
J.-H. Venhuizen and M.M. Zegers

Poujade M, Grasland-Mongrain E, Hertzog A, Jouanneau J, Chavrier P, Ladoux B, Buguin A, Silberzan P. 2007. Collective migration of an epithelial monolayer in response to a model wound. Proc Natl Acad Sci 104: 1598815993.

Prasad M, Montell DJ. 2007. Cellular and molecular mechanisms of border cell migration analyzed using timelapse live-cell imaging. Dev Cell 12: 997-1005.

Ramel D, Wang X, Laflamme C, Montell DJ, Emery G. 2013. Rab11 regulates cell-cell communication during collective cell movements. Nat Cell Biol 15: $317-$ 324.

Ratheesh A, Yap AS. 2012. A bigger picture: Classical cadherins and the dynamic actin cytoskeleton. Nat Rev Mol Cell Biol 13: 673-679.

Rausch S, Das T, Soine JR, Hofmann TW, Boehm CH, Schwarz US, Boehm H, Spatz JP. 2013. Polarizing cytoskeletal tension to induce leader cell formation during collective cell migration. Biointerphases 8: 32 .

Ravasio A, Cheddadi I, Chen T, Pereira T, Ong HT, Bertocchi C, Brugues A, Jacinto A, Kabla AJ, Toyama Y, et al. 2015. Gap geometry dictates epithelial closure efficiency. Nat Commun 6: 7683.

Reffay M, Parrini MC, Cochet-Escartin O, Ladoux B, Buguin A, Coscoy S, Amblard F, Camonis J, Silberzan P. 2014. Interplay of RhoA and mechanical forces in collective cell migration driven by leader cells. Nat Cell Biol 16: 217-223.

Revenu C, Streichan S, Dona E, Lecaudey V, Hufnagel L, Gilmour D. 2014. Quantitative cell polarity imaging defines leader-to-follower transitions during collective migration and the key role of microtubule-dependent adherens junction formation. Development 141: $1282-$ 1291.

Reymond N, Im JH, Garg R, Vega FM, Borda d'Agua B, Riou P, Cox S, Valderrama F, Muschel RJ, Ridley AJ. 2012. Cdc42 promotes transendothelial migration of cancer cells through $\beta 1$ integrin. J Cell Biol 199: 653668.

Rhee DY, Zhao X-Q, Francis RJB, Huang GY, Mably JD, Lo CW. 2009. Connexin 43 regulates epicardial cell polarity and migration in coronary vascular development. Development 136: 3185-3193.

Riahi R, Sun J, Wang S, Long M, Zhang DD, Wong PK. 2015. Notch1-Dll4 signalling and mechanical force regulate leader cell formation during collective cell migration. Nat Commun 6: 6556.

Ridley AJ. 2015. Rho GTPase signalling in cell migration. Curr Opin Cell Biol 36: 103-112.

Ridley AJ, Schwartz MA, Burridge K, Firtel RA, Ginsberg MH, Borisy G, Parsons JT, Horwitz AR. 2003. Cell migration: Integrating signals from front to back. Science 302: 1704-1709.

Rolli CG, Nakayama H, Yamaguchi K, Spatz JP, Kemkemer R, Nakanishi J. 2012. Switchable adhesive substrates: Revealing geometry dependence in collective cell behavior. Biomaterials 33: 2409-2418.

Roper K. 2012. Anisotropy of Crumbs and aPKC drives myosin cable assembly during tube formation. Dev Cell 23: $939-953$.
Roper K. 2013. Supracellular actomyosin assemblies during development. Bioarchitecture 3: 45-49.

Rorth P. 2012. Fellow travellers: Emergent properties of collective cell migration. EMBO Rep 13: 984-991.

Sander EE, van Delft S, ten Klooster JP, Reid T, van der Kammen RA, Michiels F, Collard JG. 1998. Matrix-dependent Tiam1/Rac signaling in epithelial cells promotes either cell-cell adhesion or cell migration and is regulated by phosphatidylinositol 3-kinase. J Cell Biol 143: 1385-1398.

Scarpa E, Mayor R. 2016. Collective cell migration in development. J Cell Biol 212: 143-155.

Shafaq-Zadah M, Gomes-Santos CS, Bardin S, Maiuri P, Maurin M, Iranzo J, Gautreau A, Lamaze C, Caswell P, Goud B, et al. 2016. Persistent cell migration and adhesion rely on retrograde transport of $\beta_{1}$ integrin. Nat Cell Biol 18: 54-64.

Smalley KS, Brafford P, Haass NK, Brandner JM, Brown E, Herlyn M. 2005. Up-regulated expression of zonula occludens protein-1 in human melanoma associates with $\mathrm{N}$-cadherin and contributes to invasion and adhesion. Am J Pathol 166: 1541-1554.

Stenzel D, Franco CA, Estrach S, Mettouchi A, Sauvaget D, Rosewell I, Schertel A, Armer H, Domogatskaya A, Rodin S, et al. 2011. Endothelial basement membrane limits tip cell formation by inducing Dll4/Notch signalling in vivo. EMBO Rep 12: 1135-1143.

Tambe DT, Hardin CC, Angelini TE, Rajendran K, Park CY, Serra-Picamal X, Zhou EH, Zaman MH, Butler JP, Weitz DA, et al. 2011. Collective cell guidance by cooperative intercellular forces. Nat Mater 10: 469-475.

Tanner K, Mori H, Mroue R, Bruni-Cardoso A, Bissell MJ. 2012. Coherent angular motion in the establishment of multicellular architecture of glandular tissues. Proc Natl Acad Sci 109: 1973-1978.

Theveneau E, Mayor R. 2012. Cadherins in collective cell migration of mesenchymal cells. Curr Opin Cell Biol 24: $677-684$.

Trepat X, Wasserman MR, Angelini TE, Millet E, Weitz DA, Butler JP, Fredberg JJ. 2009. Physical forces during collective cell migration. Nat Phys 5: 426-430.

Trichet L, Le Digabel J, Hawkins RJ, Vedula SR, Gupta M, Ribrault C, Hersen P, Voituriez R, Ladoux B. 2012. Evidence of a large-scale mechanosensing mechanism for cellular adaptation to substrate stiffness. Proc Natl Acad Sci 109: 6933-6938.

Tse JM, Cheng G, Tyrrell JA, Wilcox-Adelman SA, Boucher Y, Jain RK, Munn LL. 2012. Mechanical compression drives cancer cells toward invasive phenotype. Proc Natl Acad Sci 109: 911-916.

Tuomi S, Mai A, Nevo J, Laine JO, Vilkki V, Ohman TJ, Gahmberg CG, Parker PJ, Ivaska J. 2009. PKCe regulation of an $\alpha 5$ integrin-ZO- 1 complex controls lamellae formation in migrating cancer cells. Sci Signal 2: ra32.

Vicente-Manzanares M, Ma X, Adelstein RS, Horwitz AR. 2009. Non-muscle myosin II takes centre stage in cell adhesion and migration. Nat Rev Mol Cell Biol 10: $778-790$.

Vicente-Manzanares M, Newell-Litwa K, Bachir AI, Whitmore LA, Horwitz AR. 2011. Myosin IIA/IIB re- 
strict adhesive and protrusive signaling to generate front-back polarity in migrating cells. J Cell Biol 193: 381-396.

Vignjevic D, Schoumacher M, Gavert N, Janssen KP, Jih G, Lae M, Louvard D, Ben-Ze'ev A, Robine S. 2007. Fascin, a novel target of $\beta$-catenin-TCF signaling, is expressed at the invasive front of human colon cancer. Cancer Res 67: 6844-6853.

Vitorino P, Meyer T. 2008. Modular control of endothelial sheet migration. Genes Dev 22: 3268-3281.

Vitorino P, Hammer M, Kim J, Meyer T. 2011. A steering model of endothelial sheet migration recapitulates monolayer integrity and directed collective migration. Mol Cell Biol 31: 342-350.

Weavers H, Skaer H. 2014. Tip cells: Master regulators of tubulogenesis? Semin Cell Dev Biol 31: 91-99.

Weber GF, Bjerke MA, DeSimone DW. 2012. A mechanoresponsive cadherin-keratin complex directs polarized protrusive behavior and collective cell migration. Dev Cell 22: 104-115.

Wen MH, Wang JY, Chiu YT, Wang MP, Lee SP, Tai CY. 2016. $\mathrm{N}$-cadherin regulates cell migration through a Rab5-dependent temporal control of macropinocytosis. Traffic 17: 769-785.

Wennerberg K, Forget M-A, Ellerbroek SM, Arthur WT, Burridge K, Settleman J, Der CJ, Hansen SH. 2003. Rnd proteins function as RhoA antagonists by activating p190RhoGAP. Curr Biol 13: 1106-1115.

Westcott JM, Prechtl AM, Maine EA, Dang TT, Esparza MA, Sun H, Zhou Y, Xie Y, Pearson GW. 2015. An epigenetically distinct breast cancer cell subpopulation promotes collective invasion. J Clin Invest 125: 1927-1943.

Wicki A, Lehembre F, Wick N, Hantusch B, Kerjaschki D, Christofori G. 2006. Tumor invasion in the absence of epithelial-mesenchymal transition: Podoplanin-mediated remodeling of the actin cytoskeleton. Cancer Cell 9: 261-272.

Wildenberg GA, Dohn MR, Carnahan RH, Davis MA, Lobdell NA, Settleman J, Reynolds AB. 2006. p120-catenin and p190RhoGAP regulate cell-cell adhesion by coordinating antagonism between Rac and Rho. Cell 127: 1027-1039.

Wirtz-Peitz F, Zallen JA. 2009. Junctional trafficking and epithelial morphogenesis. Curr Opin Genet Dev 19: 350-356.

Wu X, Kodama A, Fuchs E. 2008. ACF7 regulates cytoskeletal-focal adhesion dynamics and migration and has ATPase activity. Cell 135: 137-148.

Xu X, Francis R, Wei CJ, Linask KL, Lo CW. 2006. Connexin 43-mediated modulation of polarized cell movement and the directional migration of cardiac neural crest cells. Development 133: 3629-3639.

Yamada S, Nelson WJ. 2007. Localized zones of Rho and Rac activities drive initiation and expansion of epithelial cell-cell adhesion. J Cell Biol 178: 517-527.

Yamaguchi N, Mizutani T, Kawabata K, Haga H. 2015. Leader cells regulate collective cell migration via Rac activation in the downstream signaling of integrin $\beta 1$ and PI3K. Sci Rep 5: 7656.

Yang Y, Jamilpour N, Yao B, Dean ZS, Riahi R, Wong PK. 2016. Probing leader cells in endothelial collective migration by plasma lithography geometric confinement. Sci Rep 6: 22707.

Yu W, O'Brien LE, Wang F, Bourne H, Mostov KE, Zegers MM. 2003. Hepatocyte growth factor switches orientation of polarity and mode of movement during morphogenesis of multicellular epithelial structures. Mol Biol Cell 14: $748-763$.

Zegers MM. 2014. 3D in vitro cell culture models of tube formation. Semin Cell Dev Biol 31: 132-140.

Zegers MM, Friedl P. 2014. Rho GTPases in collective cell migration. Small GTPases 5: e28997.

Zegers MM, Forget MA, Chernoff J, Mostov KE, ter Beest MB, Hansen SH. 2003. Pak1 and PIX regulate contact inhibition during epithelial wound healing. $E M B O J$ 22: 4155-4165. 


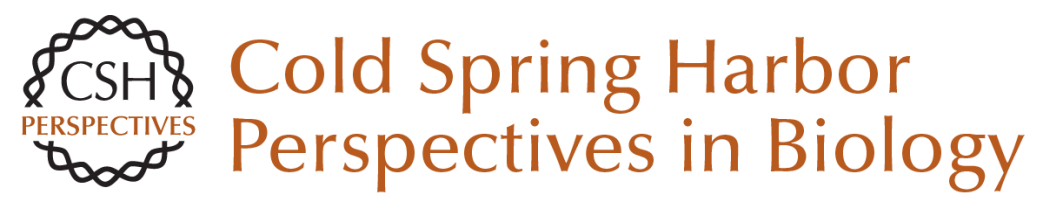

\section{Making Heads or Tails of It: Cell-Cell Adhesion in Cellular and Supracellular Polarity in Collective Migration}

Jan-Hendrik Venhuizen and Mirjam M. Zegers

Cold Spring Harb Perspect Biol 2017; doi: 10.1101/cshperspect.a027854 originally published online February 28, 2017

Subject Collection Cell Polarity

Regulation of Cell Polarity by Exocyst-Mediated

Trafficking Noemi Polgar and Ben Fogelgren

Phosphoinositides and Membrane Targeting in Cell Polarity

Gerald R. Hammond and Yang Hong

Trafficking lon Transporters to the Apical

Membrane of Polarized Intestinal Enterocytes Amy Christine Engevik and James R. Goldenring

Signaling Networks in Epithelial Tube Formation Ilenia Bernascone, Mariam Hachimi and Fernando Martin-Belmonte

Making Heads or Tails of It: Cell-Cell Adhesion in Cellular and Supracellular Polarity in Collective Migration Jan-Hendrik Venhuizen and Mirjam M. Zegers

Laminins in Epithelial Cell Polarization: Old

Questions in Search of New Answers

Karl S. Matlin, Satu-Marja Myllymäki and Aki Manninen

Epithelial Morphogenesis during Liver Development

Naoki Tanimizu and Toshihiro Mitaka
The Crumbs3 Polarity Protein

Ben Margolis

Microtubule Motors in Establishment of Epithelial Cell Polarity Geri Kreitzer and Monn Monn Myat

Role of Polarity Proteins in the Generation and

Organization of Apical Surface Protrusions Gerard Apodaca

Polarized Exocytosis Jingwen Zeng, Shanshan Feng, Bin Wu, et al.

Regulation of Transporters and Channels by Membrane-Trafficking Complexes in Epithelial Cells

Curtis T. Okamoto

Membrane Transport across Polarized Epithelia Maria Daniela Garcia-Castillo, Daniel J.-F. Chinnapen and Wayne I. Lencer

Mechanisms of Cell Polarity-Controlled Epithelial Homeostasis and Immunity in the Intestine Leon J. Klunder, Klaas Nico Faber, Gerard Dijkstra, et al.

For additional articles in this collection, see http://cshperspectives.cshlp.org/cgi/collection/

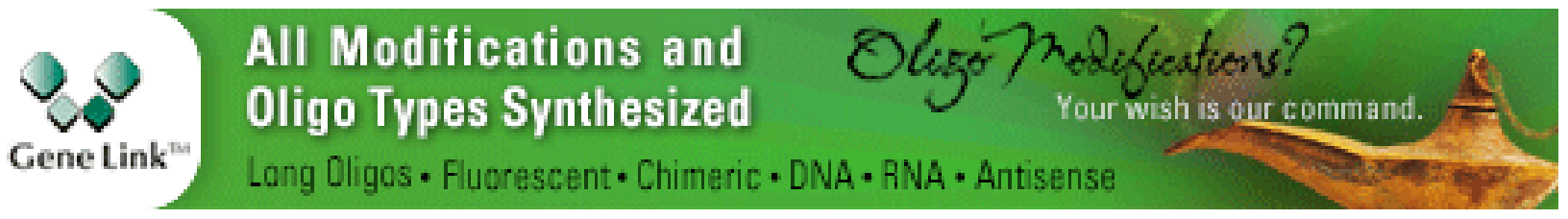


Targeting the Mucosal Barrier: How Pathogens Modulate the Cellular Polarity Network Travis R. Ruch and Joanne N. Engel
The Biology of Ciliary Dynamics

Kuo-Shun Hsu, Jen-Zen Chuang and Ching-Hwa Sung

For additional articles in this collection, see http://cshperspectives.cshlp.org/cgi/collection/

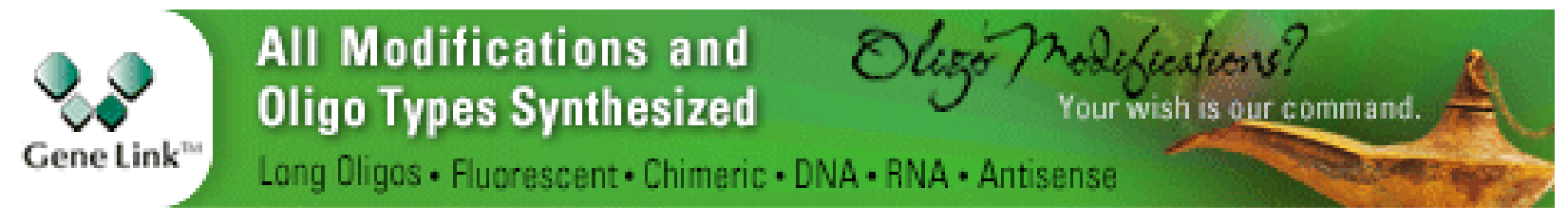

Copyright @ 2017 Cold Spring Harbor Laboratory Press; all rights reserved 